\title{
Effects of Calving Body Condition Score on Blood Acid-Base Balance of Primiparous Holstein-Friesian Dairy Cows in a Commercial Dairy Farm: A Case Study
}

\author{
Rodrigo Muiño, Joaquín Hernández *(D), José L. Benedito (D) and Cristina Castillo (D) \\ Animal Pathology Department, Veterinary School, University of Santiago de Compostela, Campus of Lugo, \\ 27002 Lugo, Spain; rodrigomuino@colvet.es (R.M.); joseluis.benedito@usc.es (J.L.B.); \\ cristina.castillo@usc.es (C.C.) \\ * Correspondence: joaquin.hernandez@usc.es; Tel.: +34-982822618
}

check for updates

Citation: Muiño, R.; Hernández, J.; Benedito, J.L.; Castillo, C. Effects of Calving Body Condition Score on Blood Acid-Base Balance of Primiparous Holstein-Friesian Dairy Cows in a Commercial Dairy Farm: A Case Study. Animals 2021, 11, 2075. https://doi.org/10.3390/ani11072075

Academic Editors: Marina Von Keyserlingk and Michael E. Davis

Received: 3 June 2021

Accepted: 11 July 2021

Published: 13 July 2021

Publisher's Note: MDPI stays neutral with regard to jurisdictional claims in published maps and institutional affiliations.

Copyright: (C) 2021 by the authors. Licensee MDPI, Basel, Switzerland. This article is an open access article distributed under the terms and conditions of the Creative Commons Attribution (CC BY) license (https:/ / creativecommons.org/licenses/by/ $4.0 /)$.
Simple Summary: This study assesses the effect of the body condition score (BCS) on productive variables and the acid-base balance in Holstein heifers. For this purpose, two groups were established according to the BCS: a group of 12 animals with an optimal BCS (range 3.25-3.5) and a group of 15 heifers with a BCS higher than 3.5. The study period started one month before calving (BC) and ran until one month after calving (AC). The results showed that the BCS of heifers does not affect milk production in terms of quantity and quality. In addition, the study of acid-base balance variables provides information that contributes additional insights into metabolic changes that can sometimes go unnoticed.

\begin{abstract}
The study was carried out on 27 healthy primiparous Holstein heifers $(620 \pm 50 \mathrm{~kg}) \mathrm{kept}$ in a commercial dairy herd. The animals were divided into two groups taking into account the body condition score (BCS) index: $\mathrm{BCS}<3.5, n=12 ; \mathrm{BCS}>3.5 n=15$. The study period started one month before calving (BC), and ran until one month after calving (AC). Venous blood samples were collected 1 month and 1 week BC, and 1 week and 1 month AC. This study had two objectives: (i) to assess whether a higher or lower BCS affected total milk production and its quality; (ii) to assess changes in the internal fluid (venous $\mathrm{pH}$; partial pressure of $\mathrm{CO}_{2}, \mathrm{ppCO}_{2}$; bicarbonate; total $\mathrm{CO}_{2}, \mathrm{TCO}_{2}$; base excess, $\mathrm{BE}$; electrolytes $\mathrm{Na}^{+}, \mathrm{K}^{+}, \mathrm{Cl}^{-}$; and anion gap, $\mathrm{AG}$ ) that occur during this phase depending on the BCS. We can conclude that the BCS at calving does not affect the productive status during lactation, both in terms of the quantity and quality of milk produced. The excess of crude protein $(\mathrm{CP})$ added through the ration in the lactation phase can trigger a tendency to an alkalotic state, in this case compensated by respiratory buffering mechanisms, as reflected by the $\mathrm{TCO}_{2}$. The changes in electrolytes are a reflection of the movement of free water for milk production, where a balance between measurable anions and cations is observed.
\end{abstract}

Keywords: heifers; parturition; body condition score; nutrition; acid-base balance; milk yield

\section{Introduction}

On a dairy farm, reproductive efficiency determines, to a large extent, the farm's profits in terms of milk production and successive pregnancies. This reproductive efficiency depends on many factors, such as the health status of the animal and the diet it receives. The Holstein breed has been selected to produce high yields at the expense of a greater propensity for losing body condition in early lactation due to a higher milk production and the absorption of nutrients preferentially by the mammary gland [1].

In general, many authors suggest that the beginning of a heifer's reproductive lifespan should be around 23-25 months [2,3] since this implies a decrease in production costs. Moreover, the same studies that recommend this age also emphasize the fact that the heifer is still in the growth phase, so nutritional and management requirements must be taken 
into account when compared to multiparous dairy cows. However, the reality is that this is a management decision peculiar to each farm.

In any case, the studies that were consulted refer to the age of the first calving as a determining factor in the incidence of numerous postpartum pathological processes, both metabolic and reproductive, which often lead the heifer to its culling [4].

Biochemical biomarkers have been used to confirm the metabolic changes that occur during calving, especially in the transition period. This stage has been widely studied, although there are still aspects to be solved. A recent review [5] extensively describes the endocrine-metabolic and inflammatory changes that take place during this critical phase, pointing to the existence of what is called metabolic stress. This situation has been chiefly based on studies on multiparous cows and biochemical parameters, especially those related to oxidative stress, the immune system or metabolic profiles. However, the parameters of acid-base balance are rarely included [6], even though blood $\mathrm{pH}$ is a reflection of the changes that occur in the internal balance, including changes in compensatory mechanisms. This lack of information may be due partly to the fact that these variables are more expensive to monitor than others, such as the body condition score (BCS) or milk production.

Indeed, a commonly used parameter has been that of the BCS as a predictor of the greater or lesser risk that a heifer may develop a more or less marked state of negative energy balance (NEB) after birth. It is recommended for all ages, that the BCS should not exceed 3.5 [7-9] according to the well-known Edmonson scale [10]. It has been reported that a high BCS and greater decline of BCS are related to high lipid mobilization and, possibly, to the incidence of metabolic disorders such as ketosis [7] in the transition period.

In accordance with the above and taking into account the scarcity of studies on the changes in the acid-base balance in heifers at calving, this study has two objectives: (1) to assess whether a higher or lower BCS affects total milk production and its quality; (2) to assess the changes in the internal fluid (venous $\mathrm{pH}$; partial pressure of $\mathrm{CO}_{2}, \mathrm{ppCO}_{2}$; bicarbonate; Total $\mathrm{CO}_{2}, \mathrm{TCO}_{2}$; Base excess, $\mathrm{BE}$; electrolytes $\mathrm{Na}^{+}, \mathrm{K}^{+}, \mathrm{Cl}^{-}$, and anion gap, $\mathrm{AG})$ that occur during this phase depending on the BCS.

We would like to emphasize that this study was conducted in a commercial dairy farm, with heifers with a highly variable BCS ranging from 3.2 to 4.5 , and in a different environment from those conducted in experimental facilities with standard management and feeding conditions. We hope that this study is of some help to veterinarians who may find themselves in similar situations since, as Cooke et al. [3] indicate, farmers need such information to make management decisions on heifer growth rates and breeding strategies.

\section{Materials and Methods}

The study was carried out on 27 healthy primiparous Holstein heifers $(620 \pm 50 \mathrm{~kg})$ at an age of $25 \pm 2$ months; kept in a commercial dairy herd located in Lugo (Galicia, North-West Spain). The sample size calculation was calculated using G*Power power analysis software, based on a predesigned effect size of a small difference between the groups, based on Cohen's principles [11].

The animals were divided into two groups taking into account the BCS index which was recorded according to the Edmonson scale [10] and where the value of 1 indicates severe under-conditioning and 5 is severe over-conditioning. This assessment was carried out by the same person. In this way, prior to the first sampling, animals were classified into two groups: in one group we included those heifers with a body condition considered adequate for the month prior to parturition (3.25-3.5, BCS $\leq 3.5$ group, mean body weight $550 \pm 10 \mathrm{~kg}$ ) and the other group was composed of those heifers with a BCS higher than 3.5, even reaching 4.5 (BCS $>3.5$ group, mean body weight $600 \pm 10 \mathrm{~kg}$ ). It is noteworthy that from this first measurement, the heifers gained around $0.8 \pm 0.1 \mathrm{~kg} /$ day. Thus, the number of animals per group was 12 heifers in the BCS $<3.5$ group and 15 in the BCS $>3.5$ group.

The study period started one month before calving (BC) and ran until one month after calving (AC) with a variation between samplings of 2-3 days for the animals included in 
each group. All heifers had a normal, easy calving (unassisted or assisted by one person) and no clinical abnormalities were seen during the postpartum period. The calving season was in autumn, between 10 and 30 October 2019. During the experimental period, all the animals were kept under identical conditions.

The diet for heifers in the prior parturition period, based on the National Research Council (NRC, 2001), consisted of a base ration, fed as a daily total mixed ration (TMR) comprising corn silage $(4 \mathrm{~kg})$, wheat straw $(6 \mathrm{~kg})$ and $5.2 \mathrm{~kg}$ of a commercial concentrate composed of rapeseed meal, barley and beetroot molasses. After calving, the diet was adjusted to maintain the requirements of milk output. The postpartum diet consisted of corn silage ( $35 \mathrm{~kg})$, grass silage $(6 \mathrm{~kg})$ and $12.6 \mathrm{~kg}$ of a specific concentrate composed of corn, rapeseed meal, soybean flour, barley and beetroot molasses. The chemical composition of both diets is shown in Table 1.

Table 1. Chemical composition of the TMR fed to the heifers during the present study.

\begin{tabular}{ccc}
\hline Chemical Composition $\left(\mathbf{g ~ k g}^{-\mathbf{1}} \mathbf{D M}\right)$ & BC $^{\mathbf{a}}$ & AC \\
\hline Crude protein (CP) & 142.7 & 171.5 \\
Neutral detergent fibre (NDF) & 433.1 & 307.9 \\
Acid detergent fibre (ADF) & 301.2 & 191.6 \\
Starch & 126.8 & 246.8 \\
Milk forage unit (UFL) & 0.76 & 0.97 \\
\hline
\end{tabular}

a $\mathrm{BC}$, before calving; $\mathrm{AC}$, after calving. All heifers received the same vitamin and mineral premix that changed depending on the studied stage. Thus, BC the composition of the premix was: $28 \mathrm{mg} / \mathrm{kg}$ of Cu; $42 \mathrm{mg} / \mathrm{kg}$ of $\mathrm{Fe} ; 2.1 \mathrm{mg} / \mathrm{kg}$ of I; $126 \mathrm{mg} / \mathrm{kg}$ of $\mathrm{Zn} ; 84 \mathrm{mg} / \mathrm{kg}$ of Mn; $0.42 \mathrm{mg} / \mathrm{kg}$ of Co; $0.63 \mathrm{mg} / \mathrm{kg}$ of Se; $16.800 \mathrm{IU}$ vitamin $\mathrm{A} / \mathrm{kg}, 5250 \mathrm{IU}$ vitamin $\mathrm{D}_{3} / \mathrm{kg}, 70 \mathrm{IU}$ vitamin $\mathrm{E} / \mathrm{kg}$. After calving (AC), the composition was: $12 \mathrm{mg} / \mathrm{kg}$ of Cu; $18 \mathrm{mg} / \mathrm{kg}$ of Fe; $0.9 \mathrm{mg} / \mathrm{kg}$ of I; $54 \mathrm{mg} / \mathrm{kg}$ of Zn; $36 \mathrm{mg} / \mathrm{kg}$ of Mn; $0.180 \mathrm{mg} / \mathrm{kg}$ of Co; $0.27 \mathrm{mg} / \mathrm{kg}$ of Se; $7.200 \mathrm{IU}$ vitamin $\mathrm{A} / \mathrm{kg}, 2250 \mathrm{IU}$ vitamin $\mathrm{D}_{3} / \mathrm{kg}, 30 \mathrm{IU}$ vitamin $\mathrm{E} / \mathrm{kg}$.

The average dry matter intake (DMI, $\mathrm{kg} / \mathrm{d}$ ) was calculated by weighing feed refusals of concentrate and straw daily at 08:00 before feeding. Thus, DMI was $11 \pm 1$ for BCS-3.5 and $10 \pm 1 \mathrm{~kg}$ for BCS $>3.5$ before parturition. After calving, the average DMI $(\mathrm{kg} / \mathrm{d})$ was $22.5 \pm 0.5$ for BCS-3.5 and $21 \pm 0.5$ for BCS $>3.5$.

All cows were housed in a free-stall barn bedded with wood shavings. The diet was offered ad libitum as a total mixed ration three times daily at 07:00, 14:00, and 20:00 $\mathrm{h}$. The experiment conducted in this report was approved by the Animal Care and Use Committee of the University of Santiago de Compostela, according to the Spanish Regulations (RD 53/2013, legal provision number 1337) and the European regulation of animals for scientific purposes (Council of Europe, ETS no.123) [12].

Venous blood samples were collected via jugular puncture at 1 month (sampling 1) and 1 week (sampling 2) before the expected calving, and at 1 week and 1 month after parturition (samplings 3 and 4, respectively). In all of the cases, samples were collected following the second meal, between 15:00 and 16:00 h.

Blood acid-base parameters and electrolytes $\left(\mathrm{pH}\right.$; partial pressure of $\mathrm{CO}_{2}, \mathrm{ppCO}_{2}$; Bicarbonate $\mathrm{HCO}_{3}{ }^{-}$; Base excess, $\mathrm{BE}$; Total $\mathrm{CO}_{2}, \mathrm{TCO}_{2} ; \mathrm{Na}^{+} ; \mathrm{K}^{+} ; \mathrm{Cl}^{-}$; and anion gap, $\mathrm{AG}$ ) were determined using whole blood samples drawn anaerobically from the jugular vein and measured immediately using a hand-held portable analyzer (i-STAT EC8+, East Windsor, NJ, USA). Physiological and pathological control blood samples were analyzed alongside the samples to provide a two-point quality control.

Samples of TMR were collected at the beginning of each stage and submitted for chemical analysis to the laboratory of the commercial dairy farm. Analytical procedures were as follows: European Union standard methods were used for starch (European Directive 99/79/EC, 1999). Both neutral detergent fiber (NDF) and acid detergent fiber (ADF) were analyzed according to the method of Van Soest et al. [13] with amylase and sodium sulfite and expressed exclusive of residual ash. Nitrogen content was determined using the combustion method according to the Dumas principle, described by the French Association of Standardization [14]. 
Milk collection was carried out by the Friesian Breeders Association of Lugo (AFRICOR) in the same week as sampling. This legally authorized company recorded the daily yields of the animals previously identified with the farm code, the identification code of the bovine, and the calving date. A milk sample from each collection was sent to the Official Dairy Analysis Laboratory of Galicia, which, using official techniques based on molecular spectroscopy techniques, determined the physicochemical composition of the raw milk (fat, proteins) as well as the number of somatic cells present in the milk (by flow cytometry). The fat/protein ratio (F/P ratio), also known as the ketosis index, was calculated from the fat and protein values. Duffield [15] and Richardt [16] defined an F/P ratio value of 1.5 as a risk level for subclinical ketosis. Since milk fat and milk protein percentages are altered in subclinical ketosis, these parameters have been investigated for their utility in defining subclinical ketosis in this study.

The somatic cell count was log transformed into a somatic cell concentration (SCCn) by the formula SCCn $=\log 2(S C C / 100,000)+3[17]$.

The data were analyzed by a Mixed Linear Effects Model with the Ime4 package [18] in $\mathrm{R}$ statistical packages, version 4.0.3 [19] to evaluate whether the sampling moment and BCS status modified the acid-base and milk yield parameters. The model included sampling (Teffect: one week and one month before calving, $\mathrm{BC}$; one week and one month after calving, AC); and BCS (TR-effect: BCS-3.5 group and 15 BCS > 3.5 group) as fixed factors, and the animal as a repeated (random) factor. The dependent variables were milk production, fat, protein, fat/protein ratio (F/P ratio), SCC count and acid-base parameters. The $p$-values for the mixed model were obtained with the ImerTest package. The descriptive values were obtained from the analysis with the emmeans (Estimated marginal Means) function. Significance was declared at $p$-values $<0.05$. Post-hoc pair analyses were performed by Tukey's honestly significant difference (HSD) test.

\section{Results}

Figure 1 shows the evolution of BCS in both groups throughout the study. Time (or physiological stage) had a significant effect $(p<0.01)$ on BCS evolution with a decrease at 1 week $\mathrm{AC}$ in both groups although it was more pronounced in those heifers included in the BCS-3.5 group (0.04 points in BCS-3.5 versus 0.02 points in BCS > 3.5). After delivery and during lactation, the $\mathrm{BCS}$ returned to the original values shown at 1 month $\mathrm{BC}$. The BCS index had a significant effect $(p<0.01)$ during the whole study period as the means of the two groups were significantly different. Nevertheless, $T^{*} \mathrm{TR}$ was not significant $(p=0.710)$.

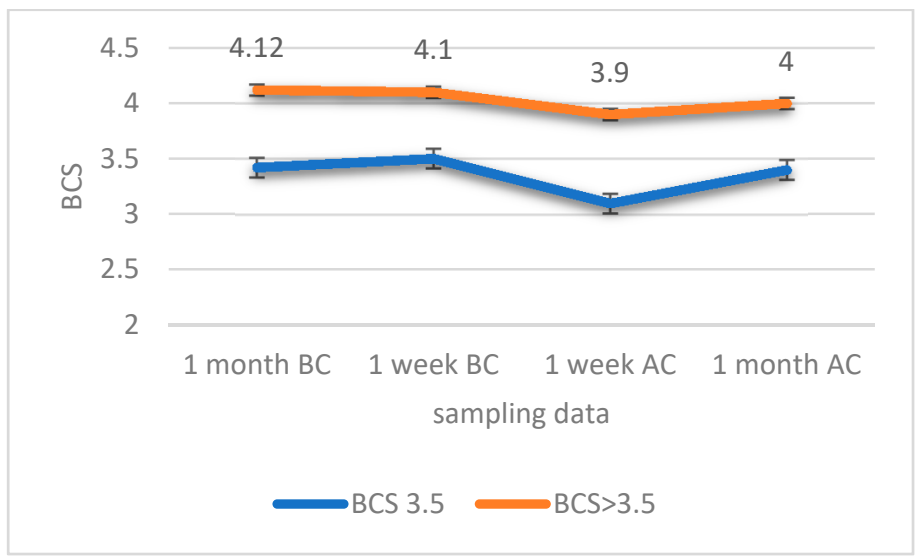

Figure 1. Body condition score (BCS) depending on the time of sampling. Standard error of the mean (SEM) for each group/sampling was 0.13; 0.0; 0.34 and 0.14 for BCS-3.5 heifers, whereas for the BCS $>3.5$ group they were $0.3 ; 0.3 ; 0.12$; and 0.3 for 1 month before calving $(\mathrm{BC})$; 1 week $\mathrm{BC}$; 1 week after calving $(\mathrm{AC})$ and 1 month $\mathrm{AC}$, respectively. 
Table 2 shows the means for milk production and milk quality in the two groups of cows. The interaction between the BCS group and the time of sampling was not significant for any of the dependent variables. Only the T-factor significantly influenced the milk yield (increased as lactation progressed) and protein percentage (decreased throughout the lactation period) independently of the BCS. Neither the fat percentage, somatic cell count, or $\mathrm{F} / \mathrm{P}$ ratio were significantly affected by $\mathrm{T}$ or $\mathrm{BCS}$.

Table 2. Mean values ( \pm standard error of the mean, SEM) of productive parameters depending on $\mathrm{BCS}$ group and their interactions during the study period.

\begin{tabular}{ccccccc}
\hline \multirow{2}{*}{ Parameter } & \multirow{2}{*}{ Group $^{\mathbf{a}}$} & \multicolumn{2}{c}{ Samplings } & \multicolumn{3}{c}{$p$-Value } \\
\cline { 2 - 7 } & & $\mathbf{1 ~ W e e k ~ A C ~}^{\mathbf{b}}$ & $\mathbf{1}$ Month AC & $\mathbf{T}$ & BCS & T $^{*}$ BCS \\
\hline Milk yield & BCS $<3.5$ & $34.1 \pm 3.5$ & $41.5 \pm 3.5$ & 0.026 & 0.638 & 0.609 \\
Kg & BCS $>3.5$ & $37.1 \pm 2.4$ & $41.9 \pm 2.4$ & & & \\
Fat & BCS $<3.5$ & $4.12 \pm 0.30$ & $4.26 \pm 1.53$ & 0.495 & 0.941 & 0.168 \\
$(\%)$ & BCS $>3.5$ & $4.42 \pm 0.30$ & $4.01 \pm 0.20$ & & & \\
Protein & BCS $<3.5$ & $3.52 \pm 0.13$ & $3.32 \pm 0.09$ & 0.016 & 0.400 & 0.722 \\
$(\%)$ & BCS $>3.5$ & $3.44 \pm 0.13$ & $3.19 \pm 0.09$ & & & \\
F/P ratio & BCS $<3.5$ & $1.17 \pm 0.08$ & $1.28 \pm 0.05$ & 0.483 & 0.519 & 0.242 \\
& BCS $>3.5$ & $1.29 \pm 0.08$ & $1.26 \pm 0.05$ & & & \\
SCCn ${ }^{\text {c }}$ & BCS $<-3.5$ & $2.87 \pm 0.57$ & $2.33 \pm 0.39$ & 0.088 & 0.659 & 0.623 \\
& BCS $>3.5$ & $2.82 \pm 0.57$ & $1.88 \pm 0.39$ & & & \\
\hline
\end{tabular}

a BCS: Body Condition Score; ${ }^{b}$ AC: after calving; ${ }^{c}$ SCCn Somatic cell concentration.

Table 3 shows the acid-base values throughout the study, as well as significant effects. None of the factors (T, BCS or $\mathrm{T}^{*} \mathrm{BCS}$ ) significantly affected the levels of venous $\mathrm{pH}$ or $\mathrm{ppCO}_{2}$, and only the T-factor had a significant effect on bicarbonate, $\mathrm{BE}$ and $\mathrm{TCO}_{2}$, increasing their values after parturition especially at 1 week $\mathrm{AC}$ (parallel with the onset of lactation), without differences between the groups.

Table 3. Mean values ( \pm standard error of the mean, SEM) of acid-base parameters depending on BCS group during the study period.

\begin{tabular}{|c|c|c|c|c|c|c|c|c|}
\hline \multirow{2}{*}{ Parameter } & \multirow{2}{*}{ Group $^{a}$} & \multicolumn{4}{|c|}{ Samplings } & \multicolumn{3}{|c|}{$p$-Value } \\
\hline & & 1 Month BC ${ }^{b}$ & 1 Week BC & 1 Week $\mathrm{AC}^{\mathrm{c}}$ & 1 Month AC & $\mathrm{T}$ & BCS & $\mathrm{T}^{*} \mathrm{BCS}$ \\
\hline Venous & BCS $<3.5$ & $7.41 \pm 0.01$ & $7.43 \pm 0.02$ & $7.44 \pm 0.01$ & $7.44 \pm 0.01$ & 0.085 & 0.594 & 0.836 \\
\hline $\mathrm{pH}$ & $\mathrm{BCS}>3.5$ & $7.42 \pm 0.01$ & $7.44 \pm 0.01$ & $7.44 \pm 0.01$ & $7.44 \pm 0.01$ & & & \\
\hline $\mathrm{pCO}_{2}$ & $\mathrm{BCS}<3.5$ & $43.8 \pm 1.92$ & $40.8 \pm 2.25$ & $44.2 \pm 0.01 \pm 1.16$ & $43.7 \pm 1.07$ & 0.073 & 0.809 & 0.868 \\
\hline$(\mathrm{mm} \mathrm{Hg})$ & $\mathrm{BCS}>3.5$ & $42.3 \pm 0.93$ & $40.6 \pm 0.87$ & $45.0 \pm 1.28$ & $43.4 \pm 1.36$ & & & \\
\hline $\mathrm{HCO}_{3}{ }^{-}$ & $\mathrm{BCS}<3.5$ & $27.7 \pm 1.53$ & $27.0 \pm 0.96$ & $30.3 \pm 2.02$ & $29.6 \pm 2.05$ & $<0.001$ & 0.899 & 0.919 \\
\hline$(\mathrm{mmol} / \mathrm{L})$ & $\mathrm{BCS}>3.5$ & $27.3 \pm 1.85$ & $27.7 \pm 1.93$ & $30.4 \pm 1.43$ & $29.5 \pm 1.68$ & & & \\
\hline $\mathrm{BE}^{\mathrm{d}}$ & $\mathrm{BCS}<3.5$ & $3.2 \pm 1.03$ & $3.0 \pm 1.19$ & $6.4 \pm 0.62$ & $5.4 \pm 0.54$ & $<0.001$ & 0.941 & 0.937 \\
\hline$(\mathrm{mmol} / \mathrm{L})$ & $\mathrm{BCS}>3.5$ & $2.8 \pm 0.50$ & $3.6 \pm 0.46$ & $6.2 \pm 0.69$ & $5.2 \pm 0.73$ & & & \\
\hline $\mathrm{TCO}_{2}$ & $\mathrm{BCS}<3.5$ & $29.0 \pm 1.77$ & $28.0 \pm 2.05$ & $31.8 \pm 1.07$ & $30.8 \pm 0.98$ & 0.32 & 0.396 & 0.370 \\
\hline$(\mathrm{mmol} / \mathrm{L})$ & $\mathrm{BCS}>3.5$ & $28.5 \pm 0.86$ & $28.8 \pm 0.79$ & $31.7 \pm 1.18$ & $27.5 \pm 1.25$ & & & \\
\hline
\end{tabular}

${ }^{\mathrm{a}}$ BCS: Body Condition Score; ${ }^{\mathrm{b}} \mathrm{BC}$ : before calving; ${ }^{\mathrm{c}}$ AC: after calving; ${ }^{\mathrm{d}}$ BE: Base excess.

Table 4 shows the average concentrations of the electrolytes measured, as well as the AG. In this case, the T-factor significantly influenced all parameters, decreasing their concentrations in both groups. 
Table 4. Mean values ( \pm standard error of the mean, SEM) of blood electrolytes depending on BCS group, time of sampling, and their interactions during the study period.

\begin{tabular}{|c|c|c|c|c|c|c|c|c|}
\hline \multirow{2}{*}{ Parameter } & \multirow{2}{*}{ Group $^{a}$} & \multicolumn{4}{|c|}{ Samplings } & \multicolumn{3}{|c|}{$p$-Value } \\
\hline & & 1 Month BC ${ }^{b}$ & 1 Week BC & 1 Week $A^{c}{ }^{c}$ & 1 Month AC & $\mathrm{T}$ & BCS & $\mathrm{T}^{*} \mathrm{BCS}$ \\
\hline $\mathrm{Na}+$ & BCS $<3.5$ & $142.2 \pm 0.9$ & $143.0 \pm 1.0$ & $142.4 \pm 0.5$ & $139.9 \pm 0.5$ & $<0.001$ & 0.933 & 0.705 \\
\hline$(\mathrm{mmol} / \mathrm{l})$ & $\mathrm{BCS}>3.5$ & $142.7 \pm 0.4$ & $143.7 \pm 0.5$ & $141.7 \pm 0.6$ & $139.6 \pm 0.6$ & & & \\
\hline $\mathrm{K}^{+}$ & BCS $<3.5$ & $3.8 \pm 0.1$ & $4.5 \pm 0.2$ & $3.5 \pm 0.1$ & $3.5 \pm 0.08$ & $<0.001$ & 0.403 & 0.235 \\
\hline$(\mathrm{mm} \mathrm{Hg})$ & $\mathrm{BCS}>3.5$ & $3.8 \pm 0.1$ & $3.9 \pm 0.1$ & $3.5 \pm 0.1$ & $3.6 \pm 0.1$ & & & \\
\hline $\mathrm{Cl}^{-}$ & $\mathrm{BCS}<3.5$ & $100.7 \pm 1.2$ & $103.3 \pm 1.4$ & $100.6 \pm 0.7$ & $98.4 \pm 0.7$ & $<0.001$ & 0.568 & 0.493 \\
\hline$(\mathrm{mmol} / \mathrm{L})$ & $\mathrm{BCS}>3.5$ & $101.8 \pm 0.6$ & $103.4 \pm 0.5$ & $99.7 \pm 0.8$ & $99.6 \pm 0.9$ & & & \\
\hline $\mathrm{AG}^{\mathrm{d}}$ & BCS $<3.5$ & $17.5 \pm 0.9$ & $16.7 \pm 1.0$ & $14.8 \pm 0.5$ & $15.4 \pm 0.5$ & $<0.001$ & 0.435 & 0.580 \\
\hline$(\mathrm{mmol} / \mathrm{L})$ & BCS > 3.5 & $17.2 \pm 0.4$ & $16.5 \pm 0.4$ & $15.1 \pm 0.6$ & $14.1 \pm 0.6$ & & & \\
\hline
\end{tabular}

${ }^{\mathrm{a}}$ BCS: Body Condition Score; ${ }^{\mathrm{b}} \mathrm{BC}$ : before calving; ${ }^{\mathrm{c}}$ AC: after calving; ${ }^{\mathrm{d}}$ AG: Anion gap.

\section{Discussion}

The aim of the study was to obtain a deeper understanding of the physiopathology of the acid-base balance in metabolically burdened dairy heifers with a high body condition in comparison with those in the same physiological situation, although with a BCS in the normal range.

Physiologically, dairy cows lose 0.5 points of the BCS after calving [9]. Increased losses of up to 0.75 points are associated with increased chances of metabolic diseases, such as ketosis. Therefore, minimizing the loss of BCS in the postpartum period ( $\leq 0.5$ points) is essential for good herd health. Around parturition, dry matter intake (DMI) decreases, resulting in a period of NEB, in which the energy demand for milk synthesis is not covered by voluntary feed intake. To meet the increased energy demands, cows mobilize body reserves predominantly from adipose tissue, promoting metabolic diseases like ketosis. However, high BCS will not necessarily lead to diseases related to metabolic disorders [20]. Obviously, some cows are able to overcome the metabolic adaptation mechanism, as is the case in our study, while others are not [21].

Our results in the farm studied, disagree with the assumptions pointed out by Puppel et al. [8] who indicated that dairy cows with a calving BSC $>3.5$, tend to have a risk of ketosis twice as high, compared to those with a BSC of 3.25. As described in later paragraphs, the heifers studied showed no significant differences for either milk production or milk quality, and thus, in ketosis risk. Clearly, the results of the animals in our study, with F/P ratios between 1.17 and 1.29 in the last week AC, were far from existing in an acidotic state caused by the development of ketosis. In addition, as pointed out by Vesna et al. [22], a characteristic of this metabolic stage, deducible from the $\mathrm{F} / \mathrm{P}$ ratio, is a decrease in milk production, which does not appear in our data.

In our study, we found a positive, but not statistically significant, relationship between BCS and milk production, a fact pointed out by different authors in the literature [23-25]. Thus, heifers with a BCS $>3.5$ show numerically higher production values one week after calving. In addition, as lactation progressed, the two BCS groups of cows became more similar in their milk production values. There is a certain similarity with the evolution of protein content, attributable to the elimination of colostrum in the first days for both groups, with a decrease at one month AC, without BCS affecting the results.

After the milk production study, and seeing the lack of significant differences between groups, we now address the changes produced in the internal balance, specifically the acid-base equilibrium.

In general terms, throughout the study the animals had a venous $\mathrm{pH}$ of $0.01-0.02$ points above the one indicated as physiological [26,27], especially after calving, which could imply a tendency towards alkalosis. This is probably due to an increase in the $\mathrm{CP}$ intake in the ration (see Table 1), and the significant increase in $\mathrm{HCO}_{3}{ }^{-}$levels and $\mathrm{BE}$ concentrations may occur as a consequence. 
The administration of diets rich in CP during lactation (according to the NRC recommendations of $12 \% \mathrm{CP}$ for heifers and from $15 \%$ to $17 \% \mathrm{CP}$ for lactating cows) is a very common nutritional management practice. However, in our case, this dietary intake may also have had a buffering effect, acting as a systemic buffer due to ammoniagenesis [28] in response to the well-known increase in metabolic activity characteristic of the onset of lactation [5], which generates an overproduction of $\mathrm{H}+$ as has been previously described [1,29]. In addition, there is a physiological condition that influences the protein content in the bodies of the studied animals: at the start of their first lactation, the competing demands of the mammary gland are superimposed on the requirements for growth.

The increase in both $\mathrm{HCO}_{3}{ }^{-}$and $\mathrm{BE}$ concentrations is counterbalanced by the increase in $\mathrm{TCO}_{2}$, helping to maintain a healthy acid-base balance in blood, and hence, the health status of the animal. This parameter is a measure of $\mathrm{CO}_{2}$ that exists in various states: $\mathrm{CO}_{2}$ in a physical solution, or slightly bound to proteins, bicarbonate or carbonic acid [26].

There is another fact connected with nutritional management that may have influenced the actions of the buffer systems: after parturition the ration was changed, increasing the content of starch and lowering the content in NDF and ADF. This type of ration, designed to increase milk production, can however, favor ruminal fermentation. This leads to a higher production of ruminal acids [30] that, in turn, are absorbed from the rumen. Thus, under these circumstances, respiratory regulation of carbonic acid in the blood is of particular importance [31].

Serum ions that are included in a chemistry acid-base profile are cations $\left(\mathrm{Na}^{+}, \mathrm{K}^{+}\right)$ and anions $\left(\mathrm{Cl}^{-}\right)$and are considered as "fixed ions" because they are bioavailable ions that are not metabolized [32]. As the main extracellular cation responsible for the osmotic force that maintains the extracellular fluid compartment [33], changes in $\mathrm{Na}^{+}$values, especially at 1-month $\mathrm{AC}$, are attributable to the increase in milk production thanks to the lactose synthesized in the udder, which implies free water movement into the udder.

Potassium, as an intracellular ion, is actively involved in cellular metabolism. In the lactating animals under study, the decrease in the values of this electrolyte with respect to the week before parturition is due to the activity of the mammary gland, which requires energy in the form of ATP for the synthesis of lactose, as has been pointed out in several studies [32]. Thanks to the increase in energy provided in the ration through the feed-not through the forage-in this phase, we can understand that although $\mathrm{K}^{+}$levels decrease, they do not reach a point that can be considered pathological. In addition, the "strong ion theory" developed by Stewart and Constable [34] suggests that milk yield and milk composition are not affected by the cation source, with $\mathrm{Na}^{+}$and $\mathrm{K}^{+}$being equally effective [35].

The evolution of $\mathrm{Na}^{+}$and $\mathrm{K}^{+}$ions is related to the systemic generation of $\mathrm{HCO}_{3}{ }^{-}$. In this line, the $\mathrm{Cl}^{-}$values, which decreased after delivery and as lactation progressed, were the result of a higher excretion as a consequence of a lower systemic generation of $\mathrm{H}+$, as shown by the venous $\mathrm{pH}$ values at this stage. In our opinion, the evolution shown by the electrolytes is due to the effect of the increase in CP content during lactation. Many consultants believe that the additional systemic ammonia provided by this type of diet may serve to buffer the high acid loads that occur during milk production, as already pointed out by Cole et al. [28].

Changes in $\mathrm{Cl}^{-}$ion concentrations are closely linked to changes in $\mathrm{Na}^{+}$ions. The decrease in chlorine values after calving, coinciding with those of $\mathrm{Na}^{+}$, is due to the free water movement that accompanies milk production and that has already been discussed in previous paragraphs.

The AG represents anions such as $\mathrm{Cl}^{-}$, proteins, phosphates, sulfates and organic anions and its increase is associated with situations of metabolic acidosis [33]. Given the lack of data showing that the animals presented acidotic processes, the decrease in the values of this parameter can only be attributed to the effect of the course of time on the electrolytes that generate their value $\left(\mathrm{Na}^{+}, \mathrm{K}^{+}, \mathrm{Cl}^{-}\right.$and $\left.\mathrm{HCO}_{3}{ }^{-}\right)$, especially the ones that are considered fixed ions [32]. 


\section{Conclusions}

After analyzing the milk production data and the acid-base data of the heifers in our study, we conclude that the BCS at calving does not affect the productive status during lactation, both in terms of the quantity and quality of milk produced.

The diet provided for each phase did not generate differences between groups. However, we can highlight that the excess of $\mathrm{CP}$ in the ration during the lactation phase can trigger a tendency to an alkalotic state, in this case compensated by respiratory buffering mechanisms, as reflected by the $\mathrm{TCO}_{2}$. The changes in electrolytes are a reflection of the movement of free water for milk production, in which a balance between measurable anions and cations is observed.

Study limitations: Considering that we were only able to observe a single group of heifers in each of the treatment groups, this study suffers from pseudoreplication and thus the findings of this case study should be viewed with extreme caution. We encourage future work to replicate this work using more groups and ideally under different farm conditions.

Author Contributions: Conceptualization, C.C.; methodology, R.M. and C.C.; software, J.H.; validation, C.C., R.M., J.H. and J.L.B.; formal analysis, J.H.; data curation, R.M. and J.L.B.; writing-original draft preparation, C.C. and J.H.; writing-review and editing, C.C., J.H. and R.M. funding acquisition, J.L.B. All authors have read and agreed to the published version of the manuscript.

Funding: This study was financed in part by Proxectos Plan Galego IDT (Code 2017-PG138) de la Consellería de Medio Rural de la Xunta de Galicia (Proyects Galician IDT Plan of the Ministry of Rural Environment of Xunta de Galicia) (FEADER 2017/057B). The title of the project was: "Sistema de control y valoración de la eficiencia de las explotaciones ganaderas para la producción sostenible de leche" (System of control and evaluation of the efficiency of livestock farms for the sustainable production of milk).

Institutional Review Board Statement: Not applicable.

Informed Consent Statement: Not applicable.

Data Availability Statement: Not applicable.

Acknowledgments: To the staff of the Chain S.L. livestock farm and especially to its owner Jose Carlos Reigada and the veterinarian of this farm Carlos Alberto Guerra for their collaboration in the realization of this study.

Conflicts of Interest: The authors declare that they have no known competing financial interests or personal relationships that could have appeared to influence the work reported in this paper.

\section{References}

1. Wathes, D.C.; Cheng, Z.; Bourne, N.; Taylor, V.J.; Coffey, M.P.; Brotherstone, S. Differences between primiparous and multiparous dairy cows in the inter-relationships between metabolic traits, milk yield and body condition score in the periparturient period. Domest. Anim. Endocrinol. 2007, 33, 203-225. [CrossRef]

2. Castillo-Badilla, G.; Salazar-Carranza, M.; Murillo-Herrera, J.; Romero-Zuñiga, J.J. Efecto de la edad al primer parto sobre parámetros productivos en vacas Jersey de Costa Rica. Agron. Mesoam. 2013, 24, 177-187. [CrossRef]

3. Cooke, J.S.; Cheng, Z.; Bourne, N.E.; Wathes, D.C. Association between growth rates, age at first calving and subsequent fertility, milk production and survival in Holstein-Friesian heifers. Open J. Anim. Sci. 2013, 3, 1-12. [CrossRef]

4. Macdonald, K.; Penno, J.; Bryant, A.; Roche, J. Effect of Feeding Level Pre- and Post-Puberty and Body Weight at First Calving on Growth, Milk Production, and Fertility in Grazing Dairy Cows. J. Dairy Sci. 2005, 88, 3363-3375. [CrossRef]

5. Abuelo, A.; Hernández, J.; Benedito, J.L.; Castillo, C. Redox Biology in Transition Periods of Dairy Cattle: Role in the Health of Periparturient and Neonatal Animals. Antioxidants 2019, 8, 20. [CrossRef] [PubMed]

6. Castillo, C.; Benedito, J.; Pereira, V.; Vázquez, P.; Gutiérrez, C.; Hernández, J. Acid-base status and serum 1-lactate in growing/finishing bull calves fed different high-grain diets. Livest. Sci. 2009, 120, 66-74. [CrossRef]

7. Bernabucci, U.; Ronchi, B.; Lacetera, N.; Nardone, A. Influence of Body Condition Score on Relationships Between Metabolic Status and Oxidative Stress in Periparturient Dairy Cows. J. Dairy Sci. 2005, 88, 2017-2026. [CrossRef]

8. Puppel, K.; Kuczyńska, B. Metabolic profiles of cow's blood; a review. J. Sci. Food Agric. 2016, 96, 4321-4328. [CrossRef]

9. Chapel, J.M.; Muiño, R.; Pereira, V.; Castillo, C.; Hernández, J.; Benedito, J.L. Relationship of BCS prepartum with reproductive performance and lipomobilization in Holstein dairy cows. Pakistan. Vet. J. 2017, 37, 215-219. 
10. Edmonson, A.J.; Lean, I.J.; Weaver, L.D.; Farver, T.; Webster, G. A Body Condition Scoring Chart for Holstein Dairy Cows. J. Dairy Sci. 1989, 72, 68-78. [CrossRef]

11. Faul, F.; Erdfelder, E.; Lang, A.-G.; Buchner, A. G*Power 3: A flexible statistical power analysis program for the social, behavioral, and biomedical sciences. Behav. Res. Methods 2007, 39, 175-191. [CrossRef]

12. Real Decreto 53/2013, de 1 de Febrero, por el que se Establecen las Normas Básicas Aplicables Para la Protección de los Animales utilizados en Experimentación y otros Fines Científicos, Incluyendo la Docencia. Boletin Oficial del Estado del Gobierno de España 34. Available online: https:/ /www.boe.es/eli/es/rd/2013/02/01/53 (accessed on 23 May 2021).

13. Van Soest, P.J.; Robertson, J.B.; Lewis, B.A. Methods for Dietary Fiber, Neutral Detergent Fiber, and Nonstarch Polysaccharides in Relation to Animal Nutrition. J. Dairy Sci. 1991, 74, 3583-3597. [CrossRef]

14. Norme Française NF V18-120, Dosage de l'azote par Combustion (Dumas); ANFOR: Paris, France, 1997.

15. Duffield, T.F. Monitoring strategies for metabolic disease in transition dairy cows. In Proceedings of the 23rd World Buiatrics Congress, Ontario, QC, Canada, 16 July 2004.

16. Richardt, W. Milk composition as an indicator of nutrition and health. Breeding 2004, 11, $26-27$.

17. Ali, A.K.A.; Shook, G.E. An Optimum Transformation for Somatic Cell Concentration in Milk. J. Dairy Sci. 1980, 63, 487-490. [CrossRef]

18. Bates, D.; Maechler, M.; Bolker, B.; Walker, S. Lme4: Linear Mixed-Effects Models Using Eigen and S4. R Package Version 1.1-8. 2015. Available online: http:/ /CRAN.R-project.org/package=lme4 (accessed on 20 February 2021).

19. R Core Team. A Language and Environment for Statistical Computing; R Foundation for Statistical Computing: Vienna, Austria, 2020; Available online: https: / / www.r-project.org/ (accessed on 20 February 2021).

20. Vernon, R.G. Lipid metabolism during lactation: A review of adipose tissue-liver interactions and the development of fatty liver. J. Dairy Res. 2005, 72, 460-469. [CrossRef]

21. Adrien, M.; Mattiauda, D.; Artegoitia, V.; Carriquiry, M.; Motta, G.; Bentancur, O.; Meikle, A. Nutritional regulation of body condition score at the initiation of the transition period in primiparous and multiparous dairy cows under grazing conditions: Milk production, resumption of post-partum ovarian cyclicity and metabolic parameters. Animal 2012, 6, 292-299. [CrossRef]

22. Vesna, G.; Potonik, K.; Jovanovac, S. Test-day records as a tool for subclinical ketosis detection. Acta Vet. 2009, 59, $185-191$. [CrossRef]

23. Pirlo, G.; Miglior, F.; Speroni, M. Effect of Age at First Calving on Production Traits and on Difference Between Milk Yield Returns and Rearing Costs in Italian Holsteins. J. Dairy Sci. 2000, 83, 603-608. [CrossRef]

24. Mayne, C.S.; Mackey, D.R.; Verner, M.; McCaughey, W.J.; Gordon, F.J.; McCoy, M.A.; Lennox, S.D.; Catney, D.C.; Wylie, A.R.G.; Kennedy, B.W. Fertility of dairy cows in Northern Ireland. Vet. Rec. 2002, 150, 707-713. [CrossRef] [PubMed]

25. Hare, E.; Norman, H.; Wright, J. Trends in Calving Ages and Calving Intervals for Dairy Cattle Breeds in the United States. J. Dairy Sci. 2006, 89, 365-370. [CrossRef]

26. Nagy, O.; Seidel, H.; Kováč, G.; Paulíková, I. Acid-base balance and blood gases in calves in relation to age and nutrition Czech. J. Anim. Sci. 2003, 48, 61-68.

27. Gärtner, T.; Zoche-Golob, V.; Redlberger, S.; Reinhold, P.; Donat, K. Acid-base assessment of post-parturient German Holstein dairy cows from jugular venous blood and urine: A comparison of the strong ion approach and traditional blood gas analysis. PLoS ONE 2019, 14, e0210948. [CrossRef] [PubMed]

28. Cole, N.A.; Greene, L.W.; Mccollum, F.T.; Montgomery, T.; McBride, K. Influence of oscillating dietary crude protein concentration on performance, acid-base balance, and nitrogen excretion of steers1,2,3. J. Anim. Sci. 2003, 81, 2660-2668. [CrossRef]

29. Wu, W.; Liu, J.; Xu, G.; Ye, J. Calcium homeostasis, acid-base balance, and health status in periparturient Holstein cows fed diets with low cation-anion difference. Livest. Sci. 2008, 117, 7-14. [CrossRef]

30. Zebeli, Q.; Mansmann, D.; Steingass, H.; Ametaj, B. Balancing diets for physically effective fibre and ruminally degradable starch: A key to lower the risk of sub-acute rumen acidosis and improve productivity of dairy cattle. Livest. Sci. 2010, 127, 1-10. [CrossRef]

31. Calamari, L.; Abeni, F.; Calegari, F.; Stefanini, L. Metabolic conditions of lactating Friesian cows during the hot season in the Po valley. 2. Blood minerals and acid-base chemistry. Int. J. Biometeorol. 2007, 52, 97-107. [CrossRef]

32. Afzaal, D.; Nisa, M.; Khan, M.A.; Sarwar, M.A. review on acid base status in dairy cows: Implications of dietary cation-anion balance. Pakistan. Vet. J. 2004, 24, 199-202.

33. Hernandez, J.; Benedito, J.L.; Castillo, C. Relevance of the study of metabolic profiles in sheep and goat flock. Present and future: A review. Span. J. Agric. Res. 2020, 18, e06R01. [CrossRef]

34. Müller, K.; Gentile, A.; Klee, W.; Constable, P. Importance of the Effective Strong Ion Difference of an Intravenous Solution in the Treatment of Diarrheic Calves with Naturally Acquired Acidemia and Strong Ion (Metabolic) Acidosis. J. Vet. Intern. Med. 2012, 26, 674-683. [CrossRef]

35. Iwaniuk, M.; Weidman, A.; Erdman, R. The effect of dietary cation-anion difference concentration and cation source on milk production and feed efficiency in lactating dairy cows. J. Dairy Sci. 2015, 98, 1950-1960. [CrossRef] [PubMed] 